\title{
The Impact of New Unionization on Wages and Working Conditions
}

\section{Citation}

Freeman, Richard Barry, and Morris M. Kleiner. 1990. The impact of new unionization on wages and working conditions. Journal of Labor Economics 8(1) Part 2: S8-S25.

\section{Published Version}

doi:10.1086/298243

\section{Permanent link}

http://nrs.harvard.edu/urn-3:HUL.InstRepos:4632238

\section{Terms of Use}

This article was downloaded from Harvard University's DASH repository, and is made available under the terms and conditions applicable to Other Posted Material, as set forth at http:// nrs.harvard.edu/urn-3:HUL.InstRepos:dash.current.terms-of-use\#LAA

\section{Share Your Story}

The Harvard community has made this article openly available.

Please share how this access benefits you. Submit a story.

\section{Accessibility}




\title{
The Impact of New Unionization on Wages and Working Conditions
}

\author{
Richard B. Freeman, Harvard University and
}

National Burean of Economic Research

\begin{abstract}
Morris M. Kleiner, University of Minnesota and
National Burean of Economic Research
\end{abstract}

This study investigates the impact of union organization on the wages and labor practices of establishments newly organized in the 1980 s. It uses a research design in which establishments are "paired" with their closest nonunion competitor. It finds that, unionism had only a modest effect on wages in the newly organized plants, which contrasts sharply with the huge union wage impact found in cross-section comparisons of union and nonunion individuals, but unionism substantially alters several personnel practices, creating grievance systems, greater seniority protection, and job bidding and posting. That newly organized establishments adopt union working conditions but grant only modest wage increases suggests that "collective voice" rather than monopoly wage gains is the key to understanding new unionism.

Studies of the economic effects of unionization have traditionally focused on differences between union and nonunion workers (Freeman and Medoff 1984; Lewis 1986), in large part because of the availability of cross-section

This study was funded by the National Science Foundation. The authors want to thank William Dickens, Casey Ichniowski, and participants at seminars at MIT and Columbia University for their comments and criticisms. We also want to thank Shelly Skie and Jan Bull for their assistance with the computations for this article.

[Journal of Labor Economics, 1990, vol. 8, no. 1, pt. 2]

(C) 1990 by The University of Chicago. All rights reserved.

0734-306X/90/0801-0012\$01.50 
and longitudinal data sets on individuals. Because unions have had little organizing success in the 1970s and 1980s, however, the vast majority of union workers in such data sets are employed in establishments that were organized decades earlier. Analyses of the wages of these workers may present a misleading picture of the economic effects of the new union organization that might be expected to influence the decisions of currently nonunion management and labor to support or oppose union organizing drives. In a period when union wage increases have fallen short of those of nonunion workers, ${ }^{1}$ and the union share of employment has contracted, the impact of newly organized unions on wages and working conditions can reasonably be expected to differ from that of existing unions.

What has been the economic impact of successful union organizing drives in the 1980s? Has new unionization raised wages substantially or altered working conditions greatly in the period? To answer these questions, in 1986 we surveyed 203 establishments that had National Labor Relations Board (NLRB) elections in the 1980s and 161 "control" firms that did not face union organizing drives. By focusing on establishments rather than workers and by using a before/after research design, we are able to examine what new unionization did to wages and benefits, personnel practices, and employment. Thus, we are able to estimate the "marginal" rather than average effects of unionization in the period.

Our principal finding is that in the 1980 s new unionization produced wage and benefit gains far below those implied by standard cross-section analyses of union wage effects. At the same time we find that newly organized workers made significant gains in the areas of grievance procedures, job posting and bidding, and seniority protection. Consistent with a modest effect of new unionism on wages, moreover, we find modestly lower growth of employment in newly unionized establishments than in our control group of establishments. While we cannot determine with any certainty the extent to which the relatively weak union impact on wages in our sample is due to the economic conditions of the 1980s (a "period" effect), the pattern of gains in first contracts (an "age" effect), or the specific characteristics of establishments that were organized in the period (a "vintage" effect), our results demonstrate that one cannot extrapolate extant estimates of union/nonunion wage differences to newly organized establishments. That newly unionized plants adopt standard union working conditions suggests, moreover, that the industrial jurisprudence (Slichter, Healy, and Livernash 1960) or collective voice (Freeman and Medoff 1984), rather than the monopoly face of unionism, is the essence of the institution.

${ }^{1}$ Estimates from Current Wage Developments from the Bureau of Labor Statistics (BLS) for January 1987 show that for the period 1981-86 union wage rates grew an average of $4.4 \%$ per year while nonunion wages increased an average of $5 \%$ per year. 
We present the evidence and arguments for these claims in three parts. In Section I we describe our survey methodology, a "semiexperimental" design that involves paired comparisons of establishments to control for unobserved differences between firms that face/do not face union organizing drives. In Section II we give our basic estimates of what new union organization does to wage and personnel practices. In Section III we probe the results for econometric problems and discuss alternative interpretations of the findings.

\section{Issues and Methodology}

Standard analyses of the union wage premium in the United States estimate that the wages of union workers exceed those of nonunion workers in cross-section data by $15 \%-25 \%$ (Lewis 1986) and that the wages of workers who switch union status in longitudinal data is about $10 \%$ higher in the union status (Freeman 1984; Lewis 1986). Neither of these estimates, however, is likely to gage accurately the impact of unionism on the wages of establishments organized in the 1980s, nor the wage costs (to firms) and benefits (to workers) of successful organizing drives. Because unions have organized few workplaces in the past two decades, estimates of union effects based on cross-section data essentially contrast the impact of unions on workers in firms organized years ago (in the 1970s and 1960s or earlier) to workers in other firms. Estimates based on longitudinal data, moreover, contrast workers who change union status by moving to or from already organized workplaces rather than contrasting workers in plants that are newly organized with those in plants that remain nonunion.

There are three reasons for expecting the economic effects of new union organization in the 1980s to differ from the wage difference between workers in already existing union and nonunion workplaces. First is the unfavorable economic environment of the period: the decline in union representation, deregulation of industries, increased foreign competition, and high unemployment that are likely to have raised the elasticity of labor demand facing newly organized labor and the reduced the ability of the unions to raise wages. ${ }^{2}$ In an environment in which many existing unions lowered their premium over nonunion labor, it is plausible to expect that new unions faced a particularly difficult task of establishing premium in the first instance. ${ }^{3}$

${ }^{2}$ In virtually all models of union behavior, increases in the elasticity of the demand for labor reduces union wage gains.

${ }^{3}$ There are two reasons for expecting new unions to have trouble raising wages significantly in this environment. First, the decline in the union premium for already organized workers can be taken as an indicator of the weakness of the demand for labor in the period. Second, newly organized workers are influenced by the pattern of wage increases (rather than levels) among already organized workers. 
Second, union impacts on newly organized workers are likely to differ from those on previously organized workers because first contracts are likely to produce different outcomes than later contracts, as has been recognized at least since the days of Paul Douglas. In his 1930 book on real wages in the United States, Douglas argued that unions pushed for especially large wage gains in their first contract, presumably to strengthen the loyalty of the newly organized workers, and that after the first contract, union wages would increase at about the same rate as nonunion wages: "Unionism, in other words, very probably does give an appreciable increase in earnings during the early period of effective organization, but during the later and more mature years of union development, the relative rate of further progress seems ... to be no more rapid on the whole for unionists than for non-unionists" (Douglas 1930, p. 564). Other analysts, however, argue the converse: that unions are less concerned with wages than with union security provisions like dues checkoffs in their first contract; thus they produce small wage gains with first contracts. In the education sector, where collective bargaining is a relatively recent phenomenon, the evidence suggests that teacher unions obtained only modest wage gains in first contracts (Freeman 1986). However, that situation could differ in the private sector.

A third reason for expecting differences in union effects between existing and newly organized plants are vintage effects due to the distinct characteristics of establishments or workers organized in the 1980s compared to those organized earlier. The infrequency of organization in the 1980s suggests, in particular, that newly organized plants were likely to have different characteristics than other plants. Labor/management relations may have been particularly poor in the plants that became union, making workers especially favorable to unions, or management may have been less opposed to unions in those plants than elsewhere, possibly because they did not foresee serious economic losses upon becoming unionized. Another potential cause of vintage effects is that workers supporting unions in the 1980 s tend to be disproportionately minority or female compared to the white males who organized decades earlier.

\section{Our Data Set}

As data sets like the Current Population Survey (CPS) and National Labor Relations Board administrative records do not provide information on economic changes associated with new union organization, we developed a new establishment-based data set to estimate the impact of new unionization in the 1980s. We developed our data through a three-step procedure.

First, we obtained from the Boston and Kansas City National Labor Relations Board districts records of establishments that had elections during the 1980s. The states covered by the two districts are generally reflective 
of the national labor relations environment. A composite ranking of privatesector union density in the states in our sample was twenty-ninth out of 51 (the District of Columbia included). ${ }^{4}$

Second, we conducted 203 on-site interviews with firms that had elections with over 20 employees in the bargaining unit. Of the 243 firms we contacted, 203 agreed to talk to us, for a response rate of $83.5 \% ; 100$ were in Boston and 103 were in Kansas City; $5 \%$ had elections in $1985 ; 31 \%$ in $1984 ; 12 \%$ in $1983 ; 10 \%$ in $1982 ; 16 \%$ in $1981 ; 16 \%$ in 1980 ; and $10 \%$ in 1979. In our original sample $8.4 \%$ went out of business or moved. To see if this was an abnormally high or low rate, we determined the status of 50 nonunion "competitor establishments" that had no organizing drive during the 1980s and found that $8.5 \%$ went out of business or moved. ${ }^{5}$ The win rate of unions in the NLRB elections in our sample was, moreover, virtually identical to the national average: unions won $39 \%$ of the elections in our sample compared to a $38 \%$ win rate for all elections conducted in 1981 with over 20 employees (Medoff 1984). The proportion of firms that lost elections and signed collective contracts was also at the national average: $64 \%$ of the elections won by unions in our sample produced signed collective contracts; this compares with the $63 \%$ reported by McDonald (1983) for the period 1979-82.

Third, we obtained data for a "control" group of nonunion establishments that did not experience organizing drives during the 1980s. Assuming that managers in the firms that experienced organizing drives had good information about close competitors, we asked them to name their two closest nonunion competitors in their region and interviewed those firms. We had less success in obtaining cooperation in this part of our study: we telephoned 362 companies and obtained 161 pairs for a response rate of $44.5 \%$. However, even with this response rate, we still ended up with matched competitors for approximately $80 \%$ of the establishments that had organizing drives.

We use our sample of control establishments to evaluate the effects of new union organization on economic outcomes in two ways: (1) by contrasting changes in wages/personnel practices in firms that faced organizing drives with all firms that did not; and (2) by comparing firms that faced drives with their "closest competitor" and analyzing the paired differences.

${ }^{4}$ The states in our sample that had NLRB election data included Arkansas, Connecticut, Iowa, Kansas, Maine, Massachusetts, Missouri, Nebraska, New Hampshire, and Vermont.

${ }^{5}$ In this case we called a random group of 80 nonunion companies that had no NLRB elections, in the same industry and area, that were in business in the same year as the NLRB election company. If the firm was no longer in business we asked a local competitor whether the firm that closed had a union present or had an NLRB election during the period of interest. If the answer to both questions was no, it was counted as having closed for purposes of our control study. 
The paired comparisons provide a potentially useful way to control for sample selection or unobserved variable problems by allowing us to contrast establishments facing organizing drives with "brother" establishments rather than with firms in general. If the pairing correctly give us sets of establishments that are more alike than other establishments in our sample, the variance of wages and benefits (other variables) between pairs prior to the organizing drive should be lower than the variance between randomly selected establishments. This is because the common component of the variation between pairs is removed by differencing. Formally, let $\operatorname{var}\left(\ln W_{i} / W_{j}\right)$ be the variance of the natural logarithm wages and benefits (other variables) between paired establishments and let $\operatorname{cov}\left(\ln W_{i}\right.$, $\ln W_{j}$ ) be the covariance between them due to common component. Then, since

$$
\begin{gathered}
\operatorname{var}\left(\ln W_{i} / W_{j}\right)=\operatorname{var} \ln W_{i}+\operatorname{var} \ln W_{j}-2 \operatorname{cov}\left(\ln W_{i}, \ln W_{j}\right) \\
\operatorname{var}\left(\ln W_{i} / W_{j}\right)<\operatorname{var} \ln W_{i}+\operatorname{var} \ln W_{j}
\end{gathered}
$$

when cov $>0$ due to a common component. In our sample, the relevant variances were var $\ln W_{i}=.022 ; \operatorname{var} \ln W_{j}=.019 ; \operatorname{var}\left(\ln W_{i} / W_{j}\right)$ $=.024$. Hence, the technique does indeed reduce unobserved differences among firms.

Before turning to our empirical analysis, we present three additional points on the data. First, note that although the sample is limited to 364 establishments, those facing organizing drives employed over 64,000 workers, while the control sample employed an additional 82,000 worker, so we are dealing with sizeable numbers of workers. Second, while the data lacks information on worker characteristics contained on CPS-type surveys, our measures of establishment characteristics and paired comparisons are likely to control for a significant proportion of the variance in wages due to differences among jobs: recent analysis of wages on establishment and worker characteristics finds that establishment characteristics account for at least as much of the variance in wages as personal (human capital) characteristics (Groshen 1986). Third, by obtaining wage and other data on establishments before as well as after the union organizating drive, we difference away persistent unmeasured characteristics of work forces among establishments.

\section{Empirical Results}

In this section we present estimates of the impact of new union organization on wages, personnel practices, and employment, first by comparing establishments that faced organizing drives to all competitor establishments and then by comparing them to their paired "closest competitors." 
Our first set of wage estimates are based on the following natural logarithm wage equation:

$$
D \ln W_{t} i=a U 1_{i}+b U 2_{i}+c U 3_{i}+d Z_{i}+e \ln W_{o i}+u_{t i},
$$

where $D \ln W_{t i}$ is the wage change at the $i$ th establishment from 1 year before the NLRB election to $t$ periods after the election or, for establishments that did not have an organizing drive, to $t$ years after their pair faced a drive.

Variables $U 1, U 2$, and $U 3$ are dummy variables reflecting the outcome of the organizing drive: whether it resulted in a union victory in the NLRB election and a collective contract $(U 1=1)$; a union victory with no contract $(U 2=1)$; or a union defeat $(U 3=1)$. Since American unions rely almost exclusively on signed collective contracts to affect outcomes, we focus on the estimated coefficients on the $U 1$ dummy variable.

Vector $Z$ is a set of control variables, including a dummy variable for the NLRB district of the firm (Boston or Kansas City); dummy variables for whether the workers were production or nonproduction employees.

The variable $W_{o i}$ is the wage at the $i$ th establishment 1 year before the organizing drive for establishments facing drives-and in the same year as the relevant pair for those without a drive. ${ }^{6}$ The error term is $u_{t i}$.

Our estimates, using paired comparisons, are based on the following equation:

$$
D \ln \left(W_{i} / W_{j}\right)_{t}=a U 1+b U 2+c U 3+d \ln \left(W_{i} / W_{j}\right)_{0}+u_{i},
$$

where $W_{i}$ is the wage in the establishment facing an organizing drive, and $W_{j}$ is the wage in its pair; $\ln \left(W_{i} / W_{j}\right)_{0}$ is the differential between the pairs 1 year before the election.

Table 1 presents the results of our analysis of changes in compensation (wages plus benefits as reported to our interviewers) for the periods from 1 year before to 1 year after the election and from 1 year before to the

${ }^{6}$ There are two different rationales for controlling for the initial wage in these calculations, based on two different underlying structural models. The first model is a regression to mean model in which we assume that establishments above or below the average wage tend to have increases that, all else the same, bring them toward the mean. The second model derives the change equation from an equation relating the level of wages to the vector of measured variables and an unobservable. Then changes in wages are obtained by subtracting the level equation in an earlier period from the level equation in $t$. If the unobservable has the same effect over time, the resultant change equation does not contain the earlier period wage. If the effect of the unobservable changes over time, it does contain the earlier period wage as a right-hand-side variable. In this case it is necessary to do a bit of econometrics to obtain consistent estimates, as we report in n. 8 below. See Freeman (1981). 


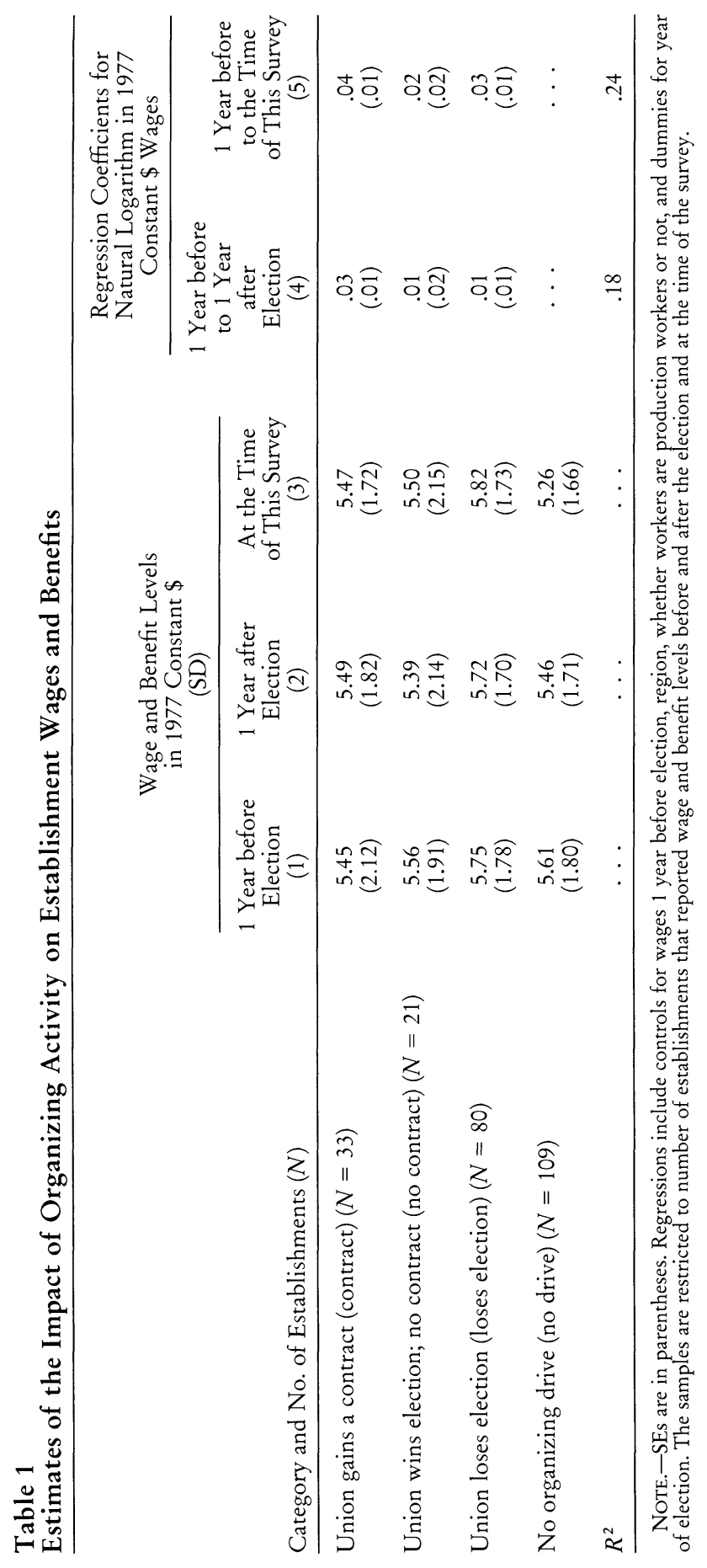


time of the survey for establishments facing organizing drives and our controls. Because some establishments did not report wages and benefits for all of these periods, our sample falls short of the full 364 by nearly a third. The bulk of the missing observations result from the absence of figures on wages and benefits prior to the organizing drive. On the basis of roughly similar wage and benefit levels, at the time of the survey, for establishments that gave complete figures and those that did not, we do not believe this data problem biases our results.

Turning to the figures, columns $1-3$ of table 1 record mean levels of compensation in constant 1977 dollars for an establishment 1 year before the election, 1 year after the election, and at the time of the survey or, in the case of establishments that did not have organizing drives, the wages at the time 1 year before and 1 year after their "pair" faced drives and at the time of the survey. The means for 1 year before the election show that establishments that faced drives had slightly lower compensation than those that did not, with plants that ended up with contracts having $2.9 \%$ lower pay than plants that did not face an organizing drive. The postelection period means show a different pattern, with pay higher in plants that faced drives, as would be expected given a direct union wage effect and potential threat effects on plants facing drives. Columns 4 and 5 present regression estimates of the impact of organizing drive outcomes on changes in wages using equation (1), with the diverse factors described there held fixed. The calculations show that workers in establishments that gained a contract had modest but statistically significantly greater increases in pay than workers in control establishments, from .03-.04 natural logarithm points. They also show that pay rose slightly but insignificantly more in plants where the union won the election but failed to gain a contract than in the controls and rose somewhat more in establishments where the union lost the election, in this case by statistically significant amounts from 1 period before to the time of the survey. ${ }^{7}$ One possible interpretation of the greater increase in wages in establishments that faced drives than in the controls is that the former raised pay to deter further organizing efforts, as predicted by models of union threat or spillover effects. Note also that the differentials between establishments that faced and did not face organizing drives rose from 1 year after the election to the time of the survey, suggesting greater direct and spillover effects of unionism as time proceeds. In no case, however, does the estimated union-induced premium approach anything like the standard union wage estimates of $15 \%-25 \%$.

${ }^{7}$ For a smaller sample of 160 establishments we were also able to examine wages 3 years prior to the election. Regressing real wages 3 years prior on our dummy variables for organizing category and controls yielded the following estimates (SEs in parentheses) of the relation between future organizing activity and those wages: union wins election and gains contract, $-.01(.02)$; union wins election but does not gain contract, .04(.03); union loses election, $-00(.01)$. Hence, there appears to be no strong relation between wages 3 years earlier and organizing outcomes. 
Table 2

Estimates of Differences in Change of Log Real Wages for an Establishment from Its Pair

\begin{tabular}{|c|c|c|c|c|}
\hline & \multirow{2}{*}{\multicolumn{2}{|c|}{$\begin{array}{l}\text { Changes in Natural Logarithm } \\
\text { Wages and Benefits in } \\
\text { Establishments Facing } \\
\text { Organizing Drives Minus } \\
\text { Changes in Its Pair }\end{array}$}} & \multicolumn{2}{|c|}{$\begin{array}{l}\text { Regression Coefficient for } \\
\text { Impact of Organizing Outcomes } \\
\text { on Log Change in Wages and } \\
\text { Benefits Relative to Its Pair }\end{array}$} \\
\hline & & & \multirow{2}{*}{$\begin{array}{l}1 \text { Year Prior } \\
\text { to } 1 \text { Year After } \\
\text { (3) }\end{array}$} & \multirow{2}{*}{$\begin{array}{l}1 \text { Year Prior } \\
\text { to Date of } \\
\text { Survey } \\
(4)\end{array}$} \\
\hline & $\begin{array}{l}1 \text { Year Prior } \\
\text { (1) }\end{array}$ & $\begin{array}{l}1 \text { Year After } \\
\text { (2) }\end{array}$ & & \\
\hline Contract & .02 & .04 & $\begin{array}{c}.00 \\
(.01)\end{array}$ & $\begin{array}{c}.07 \\
(.03)\end{array}$ \\
\hline No contract & -.01 & -.01 & $\begin{array}{c}-.04 \\
(.02)\end{array}$ & $\begin{array}{c}-.01 \\
(.03)\end{array}$ \\
\hline Loses election & .03 & .04 & $\begin{array}{c}-.00 \\
(.01)\end{array}$ & $\begin{array}{l}.04 \\
(.01)\end{array}$ \\
\hline
\end{tabular}

NOTE-SEs are in parentheses. The sample size for calculations is 62 pairs or 124 establishments. Regressions include controls for region and the differences in wages 1 year before the election.

In addition to the calculations in the table, we also estimated several other econometric specifications of equation (1). In one specification we instrumented the base-period compensation in equation (1) on the baseperiod compensation in a different period. ${ }^{8}$ In another specification we weighted observations by numbers of workers in an establishment. The results in all these experiments corroborated the findings reported in table 1.

\section{Paired Comparisons}

Table 2 presents our estimates of the difference between changes in compensation in establishments and their pair. Columns 1 and 2 record the mean of the differences between the natural logarithm changes in compensation in an establishment undergoing an organizing drive and in its pair over the specified period. They confirm the greater increase in compensation in establishments in which the union wins an election and gains a contract found in table 1; reveal slightly smaller changes in pay in establishments in which unions win but fail to gain a contract than in their nonorganizing pairs; and show modestly higher changes in compensation in establishments in which the union loses the election than in their pairs. Finally, columns 3 and 4 record the regression coefficients for the effects of the various organizing outcomes from equation (2). In these calculations

${ }^{8}$ Specifically, we regressed the wage level 1 year before the drive on the wage level 3 years before and on the other variables in the equation and used the predicted value as the control for wage level in the regression for changes in wages from 1 year before to 1 year after. This allows for the possibility that the lagged wage term will be correlated with the residual in the change equation. The instrumenting eliminates this potential source of bias. 
we omitted the constant term from the regression so that the coefficients on the organizing-drive category variables reflect the difference in pay between establishments and their pair in a given category (conditional on the year of the election and the differential 1 year before the election). For establishments where the union won a contract the estimates show greater wage increases than in their pairs from 1 year prior to the current period but not from 1 year prior to 1 year after; for establishments where unions won elections but were unable to gain contracts the estimates show negligible losses in pay relative to the pair; while for establishments where the union lost the election, the regressions show increases in compensation relative to their pair from 1 year before to the current period but not to 1 year after. The primary difference between these results and those in table 1 is the greater indication that plants that faced organizing drives obtained larger wage gains as time proceeded. Still, the key finding remains: the estimated union effects on wages in newly organized plants fall short of those obtained from CPS and other cross-section data sets, indicating that one cannot extrapolate those estimates to the margin of newly organized workplaces.

\section{Personnel Practices}

In addition to obtaining wage and benefits information from establishments that faced organizing drives and their competitors, we also asked whether firms introduced, eliminated, or left unchanged a diverse set of personnel practices, ranging from fringe benefits to seniority policies to grievance arbitration to profit sharing. As the responses showed that firms either introduced or left unchanged all practices except for profit-sharing plans, which they either eliminated or left unchanged, we coded the variables as $0-1$ dichotomies, with 0 reflecting the unchanged category and 1 reflecting a change for all practices save profit sharing; there we used the $O$ to reflect the decrease in profit-sharing and 1 to reflect maintaining a plan. We used a logistic function to estimate the impact of the organizing drive outcomes:

$$
P_{i}=1 /\left[1+\exp -\left(a U 1 i+b U 2_{i}+c U 3_{i}+d_{X} i+u_{i}\right)\right],
$$

where $P_{i}$ is the probability of introducing/eliminating a practice; and the categorical and control variables are as before.

Table 3 presents our analysis of the effect of the union organizing drives on the four personnel practices that we found were affected by new unionization. For each practice, columns 1 and 2 record the prevalence of the practice 1 year before and 1 year after the organizing drive; column 3 gives the change in the prevalence of the practice, while column 4 contrasts the change between the organizing establishments and their paired controls; finally, column 5 presents estimated logistic coefficients for equation (3). 
Table 3

Estimates of the Impact of Organizing Activity on Personnel Practices

\begin{tabular}{|c|c|c|c|c|c|}
\hline \multirow[b]{2}{*}{$\begin{array}{l}\text { Personnel Practices } \\
\text { and Organizing } \\
\text { Activity }\end{array}$} & \multicolumn{2}{|c|}{ Presence of Practice } & \multirow[b]{2}{*}{$\begin{array}{c}\Delta \text { in } \\
\text { Practice } \\
(2-1) \\
(3)\end{array}$} & \multirow[b]{2}{*}{$\begin{array}{l}\Delta \text { in } \\
\text { Practice } \\
\text { versus } \Delta \\
\text { in Pair } \\
\text { (4) }\end{array}$} & \multirow{2}{*}{$\begin{array}{c}\text { Logit } \\
\text { Coefficients } \\
\text { for Impact } \\
\text { of Organizin } \\
\text { Activity } \\
\text { on Practice } \\
(5)\end{array}$} \\
\hline & $\begin{array}{l}1 \text { Year } \\
\text { before } \\
\text { Election } \\
\text { (1) }\end{array}$ & $\begin{array}{l}1 \text { Year } \\
\text { after } \\
\text { Election } \\
\quad(2)\end{array}$ & & & \\
\hline \multicolumn{6}{|l|}{$\begin{array}{l}\text { Grievance } \\
\text { procedure: }\end{array}$} \\
\hline Contract & .38 & .86 & .48 & .35 & $\begin{array}{l}3.09 \\
(.58)\end{array}$ \\
\hline No contract & .46 & .64 & .18 & -.06 & $\begin{array}{l}.62 \\
(.90)\end{array}$ \\
\hline Loses election & .49 & .66 & .17 & .12 & $\begin{array}{l}1.01 \\
(.51)\end{array}$ \\
\hline \multicolumn{6}{|l|}{$\begin{array}{c}\text { Written seniority } \\
\text { provision: }\end{array}$} \\
\hline Contract & .42 & .70 & .28 & .23 & $\begin{array}{l}1.74 \\
(.62)\end{array}$ \\
\hline No contract & .39 & .71 & .32 & .18 & $\begin{array}{l}1.64 \\
(.71)\end{array}$ \\
\hline Loses election & .53 & .63 & .10 & .08 & $\begin{array}{l}.38 \\
(.60)\end{array}$ \\
\hline $\begin{array}{l}\text { No drive } \\
\text { Written posting of } \\
\text { promotion } \\
\text { opportunities: }\end{array}$ & .31 & .36 & .05 & $\cdots$ & $\cdots$ \\
\hline Contract & .40 & .66 & .26 & .24 & $\begin{array}{l}1.32 \\
(.52)\end{array}$ \\
\hline No contract & .61 & .75 & .14 & -.13 & $\begin{array}{l}-.75 \\
(1.10)\end{array}$ \\
\hline Loses election & .67 & .76 & .09 & -.03 & $\begin{array}{l}.05 \\
(.50)\end{array}$ \\
\hline $\begin{array}{l}\text { No drive } \\
\text { Profit sharing: }\end{array}$ & .49 & .57 & .08 & . & $\cdots$ \\
\hline Contract & .36 & .24 & -.12 & -.21 & $\begin{array}{l}-1.60 \\
(1.80)\end{array}$ \\
\hline No contract & .57 & .68 & .11 & .06 & $\begin{array}{l}-.92 \\
(1.10)\end{array}$ \\
\hline Loses election & .55 & .63 & .08 & .02 & $\begin{array}{r}-.66 \\
(.53)\end{array}$ \\
\hline No drive & .43 & .51 & .08 & $\ldots$ & $\cdots$ \\
\hline
\end{tabular}

NOTE.-SEs are in parentheses, logistic equations included. Regressions include controls for region, wages 1 year before the election, dummies for year of election, and whether workers are production workers or not. Sample size $=364$.

Consistent with cross-section analyses of the effect of unionism on fringe benefits (Freeman 1981), the results show that union contracts significantly increase the prevalence of formal grievance procedures, written seniority system for promotions or layoffs and recalls, and written posting of promotions-practices that are generally viewed as part of the "industrial jurisprudence" (Slichter, Healy, and Livernash 1960) or "collective voice". 
(Freeman and Medoff 1984) face of unionism-while reducing the prevalence of profit-sharing plans. In addition to the personnel practices in table 3, we also examined the effect of new unionism on several other practices-written sick leave, funeral leave, pensions, military/jury duty pay-and found modest, insignificant union impacts.

All told, we view the finding of significant union effects on industrial jurisprudence/voice personnel practices in the absence of large wage effects as supporting the importance of the "voice" face of unionism.

\section{Employment}

The extent to which new unionization is associated with reductions in employment at the establishment level provides a potential check on our wage and benefit findings and some insight into the issue of whether unions negotiate monopoly wage gains or efficient contracts. In general, extant research has not found substantial union employment effects with industry or state employment data, although employment has shifted away from unionized sectors and states. One interpretation of these aggregate results is that losses of employment associated with unionism may be balanced by gains to competing nonunion firms. Another is that unions negotiate sufficient job security provisions to produce efficient contracts that do not reduce employment below competitive levels. Another is that the research designs fail to capture union employment effects that occurred when unions first established their wage premia.

The evidence from our survey, based on changes in establishment employment from the time of the NLRB election to the time of the survey, present a different picture of the relation between unionization and employment than that found in more aggregated data. As can be seen in column 1 of table 4, our data show that while employment grew in control establishments, those that faced organizing drives had either no increase in employment or had reductions in employment. (This is the case where unions won the election but could not get a contract.) Column 2 of table 4 confirms this result with a regression analysis that controls for region, whether workers are production workers or not, the year the election was held, and so on. ${ }^{9}$

While some may wish to interpret these results as indicating that new unionization and union organizing drives reduce employment from what

${ }^{9}$ We also compared changes in employment in firms that faced organizing drives with the changes in their pairs. Due to the number of firms that did not report employment there were just 62 such observations, making the results suspect. Still, these calculations showed a pattern similar to that in table 5 , with plants in which unions won a contract experiencing losses of employment relative to their pair, and those in which unions won an election but could not gain a contract also showing relative declines in employment. Only the group in which unions lost the election did not show such a pattern. 


\section{Table 4}

\section{Estimates of the Impact of Union Activity on Establishment Employment Change}

\begin{tabular}{|c|c|c|}
\hline $\begin{array}{l}\text { Category (No. of } \\
\text { Establishments) }\end{array}$ & $\begin{array}{c}\text { Mean } \Delta \text { in Natural } \\
\text { Logarithm Employment: } \\
\text { Date of Election to Date } \\
\text { of Survey } \\
\text { (1) }\end{array}$ & $\begin{array}{l}\text { Regression Coefficients } \\
\text { for Natural Logarithm } \\
\Delta \text { in Employment: } \\
\text { Date of Election } \\
\text { to Date of Survey } \\
\text { (2) }\end{array}$ \\
\hline Contract $(N=48)$ & -.00 & $\begin{array}{l}-.09 \\
(.04)\end{array}$ \\
\hline No contract $(N=15)$ & -.08 & $\begin{array}{l}-.13 \\
(.04)\end{array}$ \\
\hline Loses election $(N=119)$ & .01 & $\begin{array}{r}-.06 \\
.03\end{array}$ \\
\hline No drive $(N=118)$ & .07 & $\ldots$ \\
\hline
\end{tabular}

NOTE.-SEs in parentheses. Regressions include controls for region (Boston or Kansas City) wage levels on year before the election, occupation, and year in which the election was held.

it might otherwise be, we suggest caution due to the fact that employment decreased most, absolutely and relatively, in establishments where the union won the election but could not gain a contract. If union-induced wage gains were the main factor behind the slower growth of employment in the establishments that faced drives, changes in employment should have been least where the union gained contracts, not where they failed to gain contracts: after all, table 1 showed that wages increased less rapidly in the union wins, no contract category. It is possible that our data are picking up a relation between employment patterns and the locus of organizing activity, rather than measuring the effect of collective bargaining on employment: firms experiencing drops in employment may have the types of personnel problems that lead workers to seek union protection. Unfortunately we lack employment figures over a longer period or other data to probe the observed relation. At the least, however, our analysis shows that establishment comparisons, unlike aggregate analysés, do show that firms that were organized had slower employment growth than comparison firms, which suggests that future analysis of union employment effects focus on newly organized establishments rather than aggregate data.

\section{Econometric Probes and Interpretation}

To what extent can our results be generalized beyond the samples studied? Given that we could not conduct a controlled random-assignment experiment, how applicable are our estimated modest wage effects for other establishments in the 1980s? How important are the period, age, and vintage effects-described at the outset-in explaining the difference between our results and the much larger wage estimates based on CPS-type data sets?

The question of whether our findings can be generalized beyond the 
sample relates to the potential selectivity bias in studying establishments that faced organizing drives and their close competitors. While it is common to think of selectivity bias in estimating the union wage effect in terms of the difference between the union premium conditional on the observed union (and nonunion) sample and the differential that would result from random organization of a set of workers or establishments, we do not believe that this is the most useful way to express the problem. What is relevant is not what unionization would do to a randomly chosen establishment but rather what it would do to establishments with a reasonable chance of being unionized - to firms close to the margin of being organized rather than to the average nonunion establishment. To the extent that those "marginal" firms more closely resemble the establishments in our sample than the average nonunion establishment, an estimate of what unionism would do to a randomly selected firm would provide a misleading picture of the potential effects of new organization. What one wants to know is the impact of unionization on establishment wages weighted by the probability of organization in the relevant period. In an environment where union organizing is infrequent, we believe that our sample of establishments is likely to offer a closer proxy to the desired weighted sample than a random collection of firms. The selectivity problem, then, is not one of correcting for the nonrandom nature of our sample but rather checking whether there are differences between the establishments that faced drives and their competitors that did not that might bias our estimate of the impact of unionization. We examine the issue in two ways. First, we estimate how well measured variables, prior to the organizing drive, predict which establishments face drives and, conditional on the drive, how well they predict the outcomes. Second, we add an inverse Mills correction, based on the probability of facing a drive, to our change in pay regressions and examine that calculation's impact on our estimates.

Table 5 summarizes our analysis of organizing outcomes and the impact of wages and benefits, personnel practices, and other variables before the union organizing drive. Column 1 gives maximum-likelihood estimates of a logit equation that an establishment has an organizing drive. It shows that wages and benefits do not significantly affect the probability of a drive, and that only seniority provisions and health coverage among personnel practices have discernible impacts. The presence of seniority rules raises the chance of a drive, possibly because workers in nonunion firms do not feel that supervisors apply the rule fairly, while health coverage is also associated with a higher probability of an organizing drive, for no apparent reason. Columns 2 and 3 summarize the results of similar analysis of the chances that, conditional on an election, unions would win, and, conditional on a win, that they would obtain a contract. Here, we employ a proportional hazards model that an organizing campaign has taken place (Lawless 1982). In column 2 of table 5 only one variable is significant, the presence of a written grievance procedure, which reduces the likelihood 
Table 5

Maximum-Likelihood Estimates of Organizing Category Outcomes

\begin{tabular}{lccc}
\hline Variable & $\begin{array}{c}\text { Having an } \\
\text { Organization Drive* } \\
(1)\end{array}$ & $\begin{array}{c}\text { Losing to } \\
\text { Union } \dagger \\
(2)\end{array}$ & $\begin{array}{c}\text { Signing a } \\
\text { Contract† } \\
(3)\end{array}$ \\
\hline Prior grievance & -.27 & -.67 & .63 \\
Prior seniority & $(.37)$ & $(.37)$ & $(2.43)$ \\
Prior all health & .82 & .22 & -.71 \\
Wage 1 year prior to election & $(.34)$ & $(.36)$ & $(.87)$ \\
& .54 & .50 & -1.23 \\
& $(.30)$ & $(.41)$ & $(3.25)$ \\
& -.11 & .19 & -1.14 \\
& $(.16)$ & $(.19)$ & $(1.73)$ \\
\hline
\end{tabular}

NOTE:-SEs are in parentheses. All regressions include controls for written posting or promotion opportunities, pension plan, relocation assistance, severance pay, funeral leave, military or jury duty, for region, and for whether workers were or were not production workers.

${ }_{*}^{*}$ Logistic coefficients are shown in col. 1 .

+ Hazard coefficients are shown in cols. 2 and 3.

of a union win in an election. This is consistent with evidence that "positive" labor relations reduces chances of union victories. The coefficients in column 3 yield, by contrast, no significant impact for any variable on the probability that a firm would sign a contract. None of the calculations is sufficiently striking to suggest serious selectivity bias problems in our earlier analysis.

Still, we sought to "correct" our results for possible selectivity bias by estimating a probit variant of the column 1 equation, calculating the inverse Mills ratio, and adding the term to our wage regressions. As we did not include the existence of personnel practices in the wage regression, identification comes not only from the nonlinear functional form but also from the assumption that personnel practices affect organizing drives but not future wage increases. The inverse Mills term did not enter the calculations with a significant coefficient and had only slight effects on the estimated coefficients on organizing categories. ${ }^{10}$ Hence, our major finding-that the union wage effect is much smaller for newly unionized firms than indicated by the standard cross-section estimates-is unaffected by this econometric probe.

\section{Our Results versus Cross-Section Union Wage Gaps}

Accepting our estimates as correct, what might explain the difference in magnitude between them and the union/nonunion wage differentials found in CPS and related surveys? One possibility is that the difference reflects differences between establishment-based and individual-based

${ }^{10}$ In particular, for the regression of change in wages 1 year prior to the drive to the current period, the estimated impacts (SEs in parentheses) of organizing categories was: union wins contract, .031 (.027); union wins election but fails to gain contract, $.00(.03)$; union loses election, $.04(.02)$. 
analyses, with establishment-based estimates smaller because establishment data control better for workplace-related wage differentials that are correlated with unionism than do individual-based data. Absent a detailed investigation of union wage effects from both individual and establishment sources, we are unable to assess the magnitude of this possibility, though we do believe that it is of some potential importance in explaining our results.

A second possibility is that our estimated union wage effects differ from those in cross-section studies because of the time period we have covered. To assess this, consider the differential change in union and nonunion wages in the mid 1980s as reported in Bureau of Labor Statistics' Employment Cost Index: these data show that from 1983 to 1986 compensation of union workers increased by $15.6 \%$ compared to $20.4 \%$ for nonunion workers, reducing the union premium by perhaps 5 percentage points. ${ }^{11}$ As this falls short of the 15-20 percentage-point differential between our estimated .03-.04 natural-logarithm-point union wage effect and crosssection union wage gaps, we believe that while period effects are important in explaining the differences, they are not the whole story.

A third possibility is cohort effects. As neither our analysis of the factors that caused organizing drives nor of the selectivity bias in wage regressions indicated that the firms facing drives were markedly different than their competitors, we do not believe cohort effects are that important in explaining our results. Perhaps union organizing in the 1980s was motivated by the same unmeasured management treatment of workers that industrial relations studies found to have caused successful unionization in other periods of time (Rees 1977, p. 26) rather than by any special cohort effect.

A fourth possibility is that age or first-contract effects explain much of the difference between our estimates of the impact of unionization on wages and those in CPS-type cross-section regressions. While we lack direct evidence on this point, the consistency of our findings with those on the effects of teacher unionization on newly organized school districts is certainly suggestive of first-contract effects. The finding that new union organization had substantial effects on nonwage working conditions but not on wages and benefits also seems to point in this direction. Absent data on future wage settlements in our sample, however, we cannot determine the magnitude of the first-contract effect.

\section{Conclusion}

This article has presented the results of a survey of 364 establishments covering over 146,000 workers, some which faced union organizing drives during the 1980s and some which did not face such drives. Our data show

${ }^{11}$ These changes are from December 1982 to Decmber 1986. Union compensation rose more rapidly than nonunion compensation prior to 1983. See U.S. Bureau of Labor Statistics, Employment Cost Index (various issues), quarterly. 
that firms that lost elections to unions and signed collective contracts increased wages and benefits more rapidly than control firms but fell far short of the gains needed to reach the $15 \%-25 \%$ union wage premium found in cross-section studies. Our data also show that the newly organized workers obtained substantial "voice" benefits such as grievance procedures and seniority provisions, while experiencing declines in employment compared to control firms. We hypothesize that the small wage effects that we found are likely to reflect "period" effects due to the economic environment of the 1980s and "first-contract" effects due to the tendency of new union organizations to use their bargaining power to enhance industrial democracy and decision making by rules rather than to raise wages. They may also reflect differences in the estimated size of union wage premium between establishment and individual-worker data sets.

\section{References}

Douglas, Paul H. Real Wages in the United States, 1890-1926. Cambridge, Mass.: Houghton Mifflin, 1930, p. 564.

$\rightarrow$ Freeman, Richard B. "The Effect of Unionism on Fringe Benefits." Industrial and Labor Relations Review 34, no. 4 (July 1981): 489-509.

- "Longitudinal Analyses of the Effects of Trade Unions." Journal of Labor Economics 2, no. 1 (January 1984): 1-26.

- "Unionism Comes to the Public Sector." Journal of Economic Literature 24, no. 1 (March 1986): 41-86.

Freeman, Richard, and Medoff, J. What Do Unions Do? New York: Basic, 1984.

Groshen, Erica. "Sources of Wage Dispersion: How Much Do Employers Matter?” Ph.D. dissertation, Harvard University, 1986, pp. 7-37.

Lawless, J. F. Statistical Models and Methods for Lifetime Data. New York: Wiley, 1982.

Lewis, H. Gregg. Union Relative Wage Effects: A Survey. Chicago: University of Chicago Press, 1986.

McDonald, Charles. "Memorandum to the National Organizing Committee." Washington, D.C.: AFL-CIO, 1983.

Medoff, James. "The Public's Image of Unions." Washington, D.C.: Bureau of National Affairs, December 24, 1984, pp. D-1.

Rees, Albert. The Economics of Trade Unions. rev. ed. Chicago: University of Chicago Press, 1977.

Slichter, Sumner; Healy, J.; and Livernash, E. R. The Impact of Collective Bargaining on Management. Washington, D.C.: Brookings Institution, 1960.

U.S. Department of Labor. Bureau of Labor Statistics. Current Wage Developments. Washington, D.C.: U.S. Government Printing Office, January 1987.

U.S. Department of Labor. Bureau of Labor Statistics. Employment Cost Index. Washington, D.C.: U.S. Government Printing Office, quarterly, various issues. 